\title{
Predominant Expression of $\beta_{1}$-Adrenergic Receptor in the Thick Ascending Limb of Rat Kidney \\ Absolute mRNA Quantitation by Reverse Transcription and Polymerase Chain Reaction
}

\author{
Jean-Marc Elalouf, Jean-Marie Buhler, ${ }^{\star}$ Christel Tessiot, Anne-Christine Bellanger, \\ Isabelle Dublineau, and Christian de Rouffignac \\ Département de Biologie Cellulaire et Moléculaire, Service de Biologie Cellulaire, and *Service de Biochimie et de Génétique \\ Moléculaire, Centre d'études de Saclay, 91191 Gif-sur-Yvette Cedex, France
}

\begin{abstract}
$\beta_{1}$-and $\beta_{2}$-adrenergic receptor ( $\beta$-ARs) expression in the thick ascending limb of rat kidney was studied at the level of mRNA and receptor coupling to adenylyl cyclase. Absolute quantitation of $\beta_{1}$ - and $\beta_{2}$-AR mRNAs in microdissected nephron segments was performed with an assay based on reverse transcription and polymerase chain reaction, using in vitro transcribed mutant RNAs as internal standards. In the cortical thick ascending $\operatorname{limb}$ (CTAL), the number of $\mathrm{mRNA}$ molecules $/ \mathrm{mm}$ of tubular length was $2,806 \pm 328(n=12)$ for $\beta_{1}-\mathrm{AR}$ and $159 \pm 26$ for $\beta_{2}$-AR $(P<0.01)$. Lower levels were obtained in the medullary thick ascending, $\beta_{1}$-AR mRNA still being predominant. The pharmacological properties of $\beta$-ARS was also studied in the CTAL. Cyclic AMP accumulation was stimulated by $\beta$-agonist with a rank order of potency of isoproterenol $>$ norepinephrine $>$ epinephrine. This observation, and the higher efficiency of a $\beta_{1}$ than of a $\beta_{2}$ antagonist to inhibit isoproterenol-induced cAMP accumulation, establish the typical $\beta_{1}$-AR sensitivity of the CTAL. No detectable contribution of atypical or $\beta_{3}$-ARs to adenylyl cyclase stimulation could be found. In conclusion, this study, which shows markedly different levels of $\beta_{1}$ - and $\beta_{2}$-AR mRNAS in the CTAL, provides a molecular basis for the predominant expression of the $\beta_{1}$ receptor subtype in this nephron segment. (J. Clin. Invest. 1993.91:264-272.) Key words: quantitative reverse-transcription polymerase chain reaction - sitedirected mutagenesis $\cdot$ nephron microdissection $\cdot$ cyclic adenosine monophosphate $\bullet$ catecholamines
\end{abstract}

\section{Introduction}

Catecholamine action through adenylyl cyclase-coupled $\beta$ adrenergic receptors ( $\beta$-ARs $)^{1}$ has been shown to influence a variety of renal transport processes, including $\mathrm{Cl}(1), \mathrm{Na}(1$, $2), \mathrm{Ca}$ and $\mathrm{Mg}(2)$ reabsorption as well as $\mathrm{K}(3,4)$ and bicar-

Address correspondence to Jean-Marc Elalouf, Departement de Biologie Cellulaire et Moléculaire, Service de Biologie Cellulaire, Centre d'études de Saclay, 91191 Gif-sur-Yvette, Cedex, France.

Received for publication 28 April 1992 and in revised form 5 August 1992.

1. Abbreviations used in this paper: $\beta$-AR, $\beta$-adrenergic receptor; CTAL, cortical thick ascending limb; MTAL, medullary thick ascending limb; RT-PCR, reverse transcription-polymerase chain reaction; TBE, Tris-borate EDTA; TE, Tris-EDTA.

J. Clin. Invest.

(c) The American Society for Clinical Investigation, Inc.

$0021-9738 / 93 / 01 / 0264 / 09 \$ 2.00$

Volume 91, January 1993, 264-272 bonate ( 5 ) secretion. In both rat and mouse kidney, catecholamine-sensitive adenylyl cyclase activity is mainly present in the thick ascending limb of Henle's loop and the collecting duct (6). In the thick ascending limb, the $\beta$-agonist isoproterenol increases $\mathrm{Na}, \mathrm{Cl}, \mathrm{Ca}$ and $\mathrm{Mg}$ reabsorption (2), all effects that are also elicited by several peptide hormones, including vasopressin, glucagon, calcitonin, and parathyroid hormone (7). To date, the physiological significance of such multiple hormonal control of the thick ascending limb functions has not been elucidated. However, it was proposed that the pluri-hormonal control of $\mathrm{NaCl}$ reabsorption could preserve the corticomedullary gradient in water diuresis (i.e., in the absence of vasopressin ) and thus might play a role in the urinary concentrating process (7). On the other hand, the hormone-dependent increase of $\mathrm{Mg}$ reabsorption in the thick ascending limb is generally responsible for a reduction of the $\mathrm{Mg}$ excretion rate (7). This observation opens the question of the hormonal control of Mg balance.

$\beta$-ARs are membrane receptors that stimulate adenylyl cyclase. Three subtypes of $\beta$-ARs, termed $\beta_{1}, \beta_{2}$, and $\beta_{3}$, have been characterized $(8-10)$. Nothing is known, however, about the contribution of the various $\beta$-AR subtypes to the action of catecholamines in the thick ascending limb as well as in other nephron segments. This question gains importance in view of the different affinities of these receptors for epinephrine and norepinephrine. Norepinephrine is the preferential ligand of both $\beta_{1}$-and $\beta_{3}$-ARs $(8,10,11)$ whereas epinephrine acts preferentially on the $\beta_{2}$-AR (8). In addition recent studies revealed that glucocorticoids (12) or obesity (13) alters differentially the various $\beta$-ARs at both the mRNA and protein levels. Thus, establishing the physiological significance of catecholamine action first requires a detailed characterization of the $\beta$-ARs expressed in the target cells.

Considering the structural and functional heterogeneity of the tubular segments, it is essential to determine the distribution of the various receptor subtypes in well-delineated nephron portions. Probably because of this heterogeneity, previous Northern hybridization analysis performed on whole kidney RNAs failed to detect either $\beta_{1^{-}}, \beta_{2^{-}}$, or $\beta_{3}$-AR mRNAs in the rat or mouse kidney $(8,11)$. More sensitive methods must be used to obtain this information. The amplification through reverse transcription and polymerase chain reaction (RT-PCR) offers the opportunity to detect specific mRNAs in single or small numbers of cells (14). Accordingly, we developed a quantitative RT-PCR assay to measure $\beta_{1}$ - and $\beta_{2}$-AR mRNAs in single pieces of nephron segments. This method was used to measure the steady state levels of $\beta_{1}$ - and $\beta_{2}$-AR mRNAs in microdissected rat cortical thick ascending limbs (CTAL) and revealed that the amounts of $\beta_{1^{-}}$and $\beta_{2}-\mathrm{AR}$ mRNAs greatly differed in this $n `$ phron portion. From a physi- 
ological perspective it was also important to assess whether the expression of the corresponding membrane receptors correlated with these differential mRNA levels. For this purpose, intracellular cAMP accumulation induced by $\beta$-agonists and its inhibition by specific antagonists were measured in microdissected nephron segments. These experiments allowed us to establish which $\beta$-AR subtypes are functionally coupled to the adenylyl cyclase system.

\section{Methods}

The quantitative RT-PCR assay we have elaborated requires the availability of a standard as close as possible to the mRNA of interest. This assay, as the one described by Becker-André and Hahlbrock (15), was performed using mutant RNAs that display a single or double base substitution to create a new endonuclease restriction site in the corresponding cDNA. To generate such mutated RNAs the entire coding region of the rat $\beta_{1}$ - and $\beta_{2}$-AR genes were amplified by PCR from genomic DNA and cloned into a plasmid vector carrying promoters of T3 and T7 RNA polymerases. Site-directed mutagenesis was performed on the cloned DNA fragments and known amounts of $\beta_{1}$ and $\beta_{2}$ mutant RNAs were produced by in vitro transcription. Precise amounts of the mutant RNAs were used as internal standards to determine the amounts of coamplified RNAs extracted from isolated tubules. After conversion to CDNA and PCR, the DNA fragments were treated with the appropriate restriction enzyme. Wild-type and mutant DNA fragments were discriminated by gel electrophoresis, allowing a quantitative determination of natural mRNA amounts introduced in the assay.

All the methods used for recombinant DNA procedures and RNA manipulation were from Ausubel et al. (16). The solutions used for experiments on RNAs were prepared in diethyl pyrocarbonate-treated water and were sterilized by filtration or autoclaving as appropriate. Glassware and surgery instruments were heated at $180^{\circ} \mathrm{C}$ for $8-12 \mathrm{~h}$ and were subsequently always handled with gloves. To prevent contamination, PCR and RT-PCR experiments were performed using specially designed pipettes. Restriction enzymes were from New England Biolabs (Beverly, MA).

Primer design and synthesis. For PCR and RT-PCR experiments the primers were designed with the help of Oligo software (MedProbe, Oslo, Norway). Specific $\beta_{1}$ or $\beta_{2}$ primers with $\mathrm{Tm}>60^{\circ} \mathrm{C}$ were selected. Each pair of upstream and downstream primers had closely similar Tm ( Table $I$ ). They were also checked for minimal self-priming and upper/lower dimer formation. The primers were synthetized on a DNA synthesizer (Model 380B; Applied Biosystems, Inc., Foster City, CA) by $\beta$-cyanoethyl-phosphoramidite chemistry, and then ammonia deprotected overnight and ethanol precipitated. Working solutions were stored at $-20^{\circ} \mathrm{C}$ in $10 \mathrm{mM}$ Tris- $\mathrm{HCl}, \mathrm{pH} 8 ; 1 \mathrm{mM}$ EDTA (TE) at a concentration of $5 \mathrm{pmol} / \mu \mathrm{l}$.
PCR cloning of rat $\beta_{1}$ and $\beta_{2}$-AR templates. A 1,586-bp DNA fragment encompassing the entire coding region of the rat $\beta_{1}$-AR gene (17) was amplified from $1 \mu \mathrm{g}$ of Sprague-Dawley rat genomic DNA (Stratagene, Inc., San Diego, CA) by PCR using primers listed in Table I. The 5 ' end of the upper primer located 14 nucleotides upstream to the ATG codon, and the $5^{\prime}$ end of the lower primer located 271 nucleotides downstream to the stop codon. Amplification was carried out using a Hybaid Thermal reactor with $0.2 \mu \mathrm{M}$ of each primer, $100 \mu \mathrm{M}$ dNTP, 4 $\mathrm{mM} \mathrm{MgSO}_{4}, 20 \mathrm{mM}$ Tris- $\mathrm{HCl}(\mathrm{pH} 8.8), 10 \mathrm{mM} \mathrm{KCl}, 10 \mathrm{mM}$ $\mathrm{NH}_{4} \mathrm{SO}_{4}, 0.1 \%$ Triton X-100 and $100 \mu \mathrm{g} / \mathrm{ml}$ of Dnase-Rnase-free acetylated BSA in a final volume of $75 \mu \mathrm{l}$. The reagents were mixed in a polypropylene tube kept on ice and then placed in the thermocycler at a holding temperature of $80^{\circ} \mathrm{C}$. To avoid cooling of the sample, the enzyme ( $1 \mathrm{U}$ of Vent Polymerase [New England Biolabs] in a volume of $25 \mu \mathrm{l}$ ) was slowly added along the tube wall. The solution was mixed by repeated filling of the pipette tip. It was then overlaid with three droplets of mineral oil and processed for 35 cycles of three temperature steps: $98^{\circ} \mathrm{C}(15 \mathrm{~s}$, denaturation $), 68^{\circ} \mathrm{C}(30 \mathrm{~s}$, annealing $)$, and $72^{\circ} \mathrm{C}$ ( $2.5 \mathrm{~min}$, elongation). One additional cycle was performed using an elongation time of $10 \mathrm{~min}$.

With regards to the $\beta_{2}$-AR gene, a 1,842-bp DNA fragment encompassing the entire coding region of the rat $\beta_{2}$-AR $(18,19)$ was also produced by PCR from $1 \mu \mathrm{g}$ of Sprague-Dawley rat genomic DNA. The upstream primer was a $23-\operatorname{mer}\left(5^{\prime}\right.$ end located 55 nucleotides upstream to the initiation codon) and the downstream primer was a $25-\mathrm{mer}\left(5^{\prime}\right.$ end located 532 nucleotides downstream the stop codon)(see Table I). Amplification was carried out with $1.25 \mathrm{U}$ of Thermus aquaticus DNA polymerase (Taq polymerase; Beckman Instruments, Inc., Fullerton, CA ), $0.25 \mu \mathrm{M}$ of each primer, $75 \mu \mathrm{M} \mathrm{dNTP}, 3 \mathrm{mM} \mathrm{MgCl}, 10 \mathrm{mM}$ Tris- $\mathrm{HCl}$ ( $\mathrm{pH} 8.3$ ), $50 \mathrm{mM} \mathrm{KCl}, 5 \mathrm{mM}$ DTT, and $100 \mu \mathrm{g} / \mathrm{ml}$ gelatin in a final volume of $100 \mu \mathrm{l}$. The tubes were processed as described above and submitted to 35 cycles as follows: $97^{\circ} \mathrm{C}$ for $15 \mathrm{~s}, 61^{\circ} \mathrm{C}$ for $30 \mathrm{~s}$, and $72^{\circ} \mathrm{C}$ for $1.5 \mathrm{~min}$. One additional cycle with an elongation time of 5 min was carried out.

The PCR products were analyzed by agarose gel electrophoresis. To further characterize the DNA to be cloned, the 1,586-bp $\left(\beta_{1}\right)$ and the 1,842-bp $\left(\beta_{2}\right)$ fragments were recovered from the gel with Gene Clean (BIO 101, Inc., Vista, CA). Digestion of these fragments with a set of restriction enzymes always gave products of the expected size (data not shown).

Site-directed mutagenesis of $\beta_{1}$ and $\beta_{2}$-AR templates. The $\beta$-AR DNA fragments were cloned into P Bluescript (BSSK + ) vector linearized at SmaI $\left(\beta_{1}\right)$ or $\operatorname{EcoRV}\left(\beta_{2}\right)$ sites. The clones selected displayed positive and reverse orientation for $\beta_{1}$ and $\beta_{2}$, respectively. Mutants were generated according to the method of Kunkel et al. (20) using primers containing a single $\left(\beta_{1}\right)$ or a double $\left(\beta_{2}\right)$ mismatch (see Table I) to produce a new ( $\mathrm{Xhol})$ restriction site.

In vitro transcription. Mutated sense RNAs were transcribed from 1 $\mu \mathrm{g}$ of EcoRI-cut DNA templates. Transcription was performed in a $25-\mu$ l reaction volume containing $20 \mathrm{mM}$ Tris- $\mathrm{HCl}(\mathrm{pH} 8), 4 \mathrm{mM}$

Table I. Oligonucleotide Primers Used in this Study

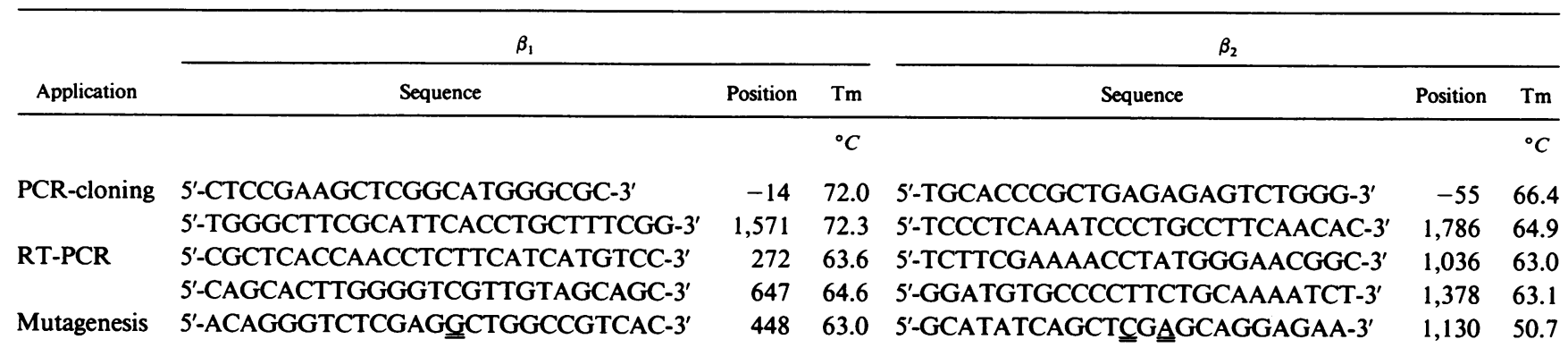

Positions of the $5^{\prime}$ ends of the primers are numbered from the ATG initiation codon of the $\beta_{1}$ - and $\beta_{2}$-AR genes. Tm values were calculated with the program OLIGO. Base substitutions (underlined) are as follows: $G$ replaces $T$ in $\beta_{1} ; C$ and $A$ replace $G$ residues in $\beta_{2}$. 
$\mathrm{MgCl}_{2}, 1 \mathrm{mM}$ spermidine, $250 \mathrm{mM} \mathrm{NaCl}, 0.4 \mathrm{mM}$ of each nucleotide, $10 \mu \mathrm{Ci}$ of $\alpha\left({ }^{32} \mathrm{P}\right) \mathrm{UTP}(400 \mathrm{Ci} / \mathrm{mmol})$, and $3 \mathrm{U}$ of T3 or T7 RNA polymerase (Stratagene, Inc.) as appropriate. Incubation was carried out at $37^{\circ} \mathrm{C}$ for $30 \mathrm{~min}$. DNA templates were then digested at $37^{\circ} \mathrm{C}$ with $5 \mathrm{U}$ of Rnase-free Dnase (Stratagene, Inc.) during an additional 1-h incubation period. The mixture was then treated with Proteinase $\mathrm{K}$ (Boehringer Mannheim GmbH, Mannheim, Germany), extracted with phenol-chloroform-isoamylalcohol ( $\mathrm{PCI}$ ), and precipitated with ethanol. The pellet was resuspended in RNA dilution buffer (TE pH 7.6; DTT, $2 \mathrm{mM}$; actylated BSA, $100 \mu \mathrm{g} / \mathrm{ml}$; Rnasin (Promega Corp., Madison, WI ), $40 \mathrm{U} / \mathrm{ml}$ ). The amount of RNA synthesized was measured by liquid-scintillation counting of the TCA-precipitated material. 4-5 pmol of RNA were obtained per reaction. Size and homogeneity of the product were checked by agarose gel electrophoresis and autoradiography.

$R T$-PCR of $\beta_{1}$ and $\beta_{2}-A R m R N A S$. The $\beta_{1}$ primers corresponded to bases 272-298 and 623-647 of the coding region, giving a DNA fragment of $376 \mathrm{bp}$. The $\beta_{2}$ primers corresponded to bases $1,036-1,059$ (upstream primer, located in the coding region) and 1,355-1,378 (downstream primer, located in the $3^{\prime}$ untranslated region), giving a DNA fragment of $343 \mathrm{bp}$. To minimize sample handling and contamination, RT and PCR steps were performed sequentially in the same reaction tube. To a final volume of $25 \mu$, the following compounds were added and maintained on ice: $2.5 \mu \mathrm{l}$ of $10 \times$ PCR buffer $(200 \mathrm{mM}$ Tris- $\mathrm{HCl}$ ( $\mathrm{pH} \mathrm{8.3),} 500 \mathrm{mM} \mathrm{KCl}, 15 \mathrm{mM} \mathrm{MgCl}_{2}, 1 \mathrm{mg} / \mathrm{ml}$ gelatin), RNAs obtained from isolated segments, known amounts of $\beta_{1}$ or $\beta_{2}$ mutant RNAs (used as internal standards), and the corresponding downstream primer $(6.25 \mathrm{pmol})$. The tubes were heated $2 \mathrm{~min}$ at $80^{\circ} \mathrm{C}$ in the thermocycler to break up secondary structures and then equilibrated at $42^{\circ} \mathrm{C}$. Each sample was supplemented with $25 \mu \mathrm{l}$ of RT mix containing $2.5 \mu \mathrm{l}$ of PCR buffer, $200 \mu \mathrm{M}$ of each dNTP, $1 \mu \mathrm{Ci} / \mathrm{nmol}$ of $\left.\alpha{ }^{32} \mathrm{P}\right] \mathrm{dCTP}, 4 \mathrm{mM} \mathrm{MgCl}, 6.4 \mathrm{mM}$ DTT with or without $200 \mathrm{U}$ of Moloney Murine Leukemia virus reverse transcriptase (Bethesda Research Laboratories, Gaithersburg, MD). The RT reaction lasted 45 min and was carried out at $42^{\circ} \mathrm{C}$ to prevent excessive mispriming and possible RNA refolding. After completion of RT, the temperature was raised to $96^{\circ} \mathrm{C}$ for $30 \mathrm{~s}$ to inactivate the enzyme and denaturate the RNA-DNA hybrid and then was equilibrated at $80^{\circ} \mathrm{C}$. The amplification reaction was initiated by adding $50 \mu \mathrm{l}$ of a mix containing $5 \mu \mathrm{l}$ of PCR buffer, $6.25 \mathrm{pmol}$ of the upper primer, and $1.25 \mathrm{U}$ of Taq polymerase. The samples were overlaid with mineral oil and submitted to the following sequential steps: $96^{\circ} \mathrm{C}, 30 \mathrm{~s} ; 64^{\circ} \mathrm{C}, 30 \mathrm{~s}$; and $74^{\circ} \mathrm{C}, 1 \mathrm{~min} .28$ PCR cycles were performed for experiments performed with $\alpha\left[{ }^{32} \mathrm{P}\right]-$ dCTP; 35 cycles were used when DNA was analyzed by ethidium-bromide staining. In all cases, the final elongation step lasted $10 \mathrm{~min}$.

Quantitative analysis of $R T-P C R$ products. To discriminate DNAs formed from wild-type and mutant RNAs, the PCR samples were Xhol digested $\left(90 \mathrm{~min}\right.$ at $37^{\circ} \mathrm{C}$ ) by adding $10 \mu$ lof the adequate digestion buffer, $10 \mathrm{U}$ of enzyme, and $100 \mu \mathrm{g} / \mathrm{ml}$ of acetylated BSA. It was checked that these conditions ensure complete digestion of mutant DNA fragments. $15 \mu$ l of the reaction was electrophoresed through a $3 \%$ ( $1 \%$ agarose, $2 \%$ low melting point agarose) agarose slab gel in TBE. The gel was fixed in $10 \%$ acetic acid, dried on $3 \mathrm{MM}$ paper (Whatman Inc., Clifton, $\mathrm{NJ}$ ) at $70^{\circ} \mathrm{C}$, and submitted to autoradiography. Several exposures were always performed to obtain nonsaturated images of all samples. Band intensity was recorded by densitometry. In each experiment, serial dilutions of RNAs obtained from nephron segments were always amplified simultaneously to fixed amounts of internal standards. The number of mRNA molecules in isolated tubules was calculated from samples in which the ratio of the signals obtained from the wild-type DNA to the mutant DNA was close to unity (see Figs. 4 and 5 ). Results are expressed as number of mRNA molecules per millimeter of tubular length.

Isolation of nephron segments. The experiments were performed on male Sprague-Dawley rats that had free access to water and standard laboratory chow until anesthesia. Nephron segments were obtained by microdissection, as previously described (21). After anesthesia (Nembutal, $5 \mathrm{mg} / 100 \mathrm{~g}$ ), the left kidney was perfused with collagenase ( 2 $\mathrm{mg} / \mathrm{ml}$ ), dissolved in the microdissection solution with the following composition (mM): $137 \mathrm{NaCl}, 5 \mathrm{KCl}, 0.8 \mathrm{MgSO}_{4}, 0.34 \mathrm{NaH}_{2} \mathrm{PO}_{4}$, $0.44 \mathrm{KH}_{2} \mathrm{PO}_{4}, 1 \mathrm{MgCl}_{2}, 1 \mathrm{CaCl}_{2}, 4 \mathrm{NaHCO}_{3}, 10 \mathrm{CH} 3 \mathrm{CO}_{2} \mathrm{Na}, 5 \mathrm{D}-\mathrm{Glu}-$ cose, 20 Hepes, and protease-free BSA $(1 \mathrm{mg} / \mathrm{ml}$, Fraction V; Miles Inc., West Haven, $\mathrm{CT})(\mathrm{pH} 7.5)$. For RNA extraction experiments this medium was made from Hanks' sterile solution (Eurobio, Les Ulis, France) and for cAMP accumulation studies it also contained $0.5 \mathrm{mM}$ ascorbic acid, as antioxydant, and $5 \mu \mathrm{M}$ indomethacin (21). Thin pyramids cut along the corticomedullary axis were incubated for 20-25 min at $30^{\circ} \mathrm{C}$ in the microdissection solution containing $1 \mathrm{mg} / \mathrm{ml}$ collagenase, continuously bubbled with air. The pyramids were then rinsed thoroughly in ice-cold microdissection solution and kept on ice in a Petri dish containing the same medium. The segments were microdissected at $4^{\circ} \mathrm{C}$ under stereomicroscopic observation using thin needles. CTAL were obtained from the medullary rays, and medullary thick ascending limbs (MTAL) were obtained from the inner stripe of the outer medulla. Tubular length was measured with an ocular micrometer either directly in the microdissection Petri dish or, for cAMP accumulation studies, after transfer of the tubules onto glass slides (21).

$R N A$ extraction from isolated tubules. Total RNAs were extracted using a microadaptation of the method described by Chomczynski and Sacchi (22). After microdissection, the tubules were transferred by pipetting to a second Petri dish containing fresh microdissection solution. They were dragged from one side to the other of the dish with microdissection needles to get structures free of contaminating cells or debris. Either single segments or pools of tubules (1-40 mm) were transferred with 5-10 $\mu$ l of microdissection solution into $400 \mu \mathrm{l}$ of denaturing solution containing $4 \mathrm{M}$ guanidinium thiocyanate, $25 \mathrm{mM}$ sodium citrate ( $\mathrm{pH} 7$ ), $0.5 \%$ sarcosyl, and $0.1 \mathrm{M} \beta$-mercaptoethanol. $10 \mu \mathrm{g}$ of yeast RNA (Pharmacia Inc., Piscataway, $\mathrm{NJ}$ ), used as carrier for microextraction, was added just before transferring the tubular segments. The suspension was immediately mixed by vortexing. Sequentially, $40 \mu \mathrm{l}$ of $2 \mathrm{M} \mathrm{CH}_{3} \mathrm{CO}_{2} \mathrm{Na}(\mathrm{pH} 4), 400 \mu$ l of water-saturated phenol, and $80 \mu \mathrm{l}$ of chloroform were added, with $20 \mathrm{~s}$ of mixing by vortexing after addition of each reagent. The final suspension was cooled on ice for $15 \mathrm{~min}$ and then centrifuged at $10,000 \mathrm{~g}$ for $20 \mathrm{~min}$ at $4^{\circ} \mathrm{C}$. The supernatant was transferred to a fresh tube, mixed with $450 \mu \mathrm{l}$ of isopropanol, and cooled $15 \mathrm{~min}$ at $4^{\circ} \mathrm{C}$. The tubes were centrifuged at $17,000 \mathrm{~g}$ for $30 \mathrm{~min}$ at $4^{\circ} \mathrm{C}$ and the RNA pellet was dissolved in 100 $\mu \mathrm{l}$ of denaturing solution. After adding $100 \mu \mathrm{l}$ of ice-cold isopropanol, centrifugation $(17,000 \mathrm{~g})$ was again performed for $20 \mathrm{~min}$ at $4^{\circ} \mathrm{C}$. The RNA pellet was washed two times in $75 \%$ ethanol, sedimented, and vacuum dried. The final pellet was dissolved in 10-20 $\mu$ l of RNA dilution buffer and stored at $-80^{\circ} \mathrm{C}$ until RT-PCR. All these steps were performed in 1.5-ml polypropylene tubes.

The yield of the entire procedure was evaluated by extracting in the same way a radiolabeled RNA synthetized from the cloned $\beta_{1}$-AR gene. Less than $10 \%(8 \pm 2 \%, n=5)$ of TCA-precipitated radioactivity was lost in the organic and ethanol phases, indicating that RNA recovery was essentially complete. Another approach consisted of adding into the denaturing solution both tubular segments and known amounts of $\beta_{1}$ or $\beta_{2}$ mutant RNAs ( see Fig. 5). In this case, the number of mRNA molecules per nephron segment was calculated, after RTPCR and Xhol digestion, from the amount of mutant mulecules introduced initially; the possible loss during extraction being considered equivalent for all RNA species. This protocol gave results identical to those obtained when the mutant RNAs were added only for the RTPCR reaction (see Figs. 4 and 6 for comparison).

cAMP accumulation studies. The nephron segments, stored on sealed glass slides in $2 \mu \mathrm{l}$ of microdissection solution supplemented with bacitracin $(1 \mathrm{mg} / \mathrm{ml})$, were preincubated $10 \mathrm{~min}$ at $30^{\circ} \mathrm{C}$. Incubation was initiated by adding $2 \mu \mathrm{l}$ of microdissection solution containing 3-isobutyl-1-methylxanthine ( $1 \mathrm{mM}$ final concentration) and the tested agent(s). For studies on the inhibition of cAMP accumulation, antagonists and isoproterenol were added simultaneously. The incubation $\left(4 \mathrm{~min}\right.$ at $35^{\circ} \mathrm{C}$ ) was stopped by transferring the segments by pipette onto a $10-\mu$ l droplet of formic acid in absolute ethanol $(5 \%$, $\mathrm{vol} / \mathrm{vol}$ ) in a polypropylene tube. After overnight evaporation to dry- 
ness, $50 \mu \mathrm{l}$ of $50 \mathrm{mM}$ potassium phosphate buffer ( $\mathrm{pH} \mathrm{6.2)} \mathrm{was} \mathrm{added}$ and the samples were kept frozen at $-20^{\circ} \mathrm{C}$ until determination of cAMP content. CAMP was measured on acetylated samples using an enzyme immunoassay enabling amounts of cAMP of between 5 and $130 \mathrm{fmol}$ per tube to be measured accurately (21). Each experiment consisted of several replicate samples (mean $\pm \mathrm{SD}, 7 \pm 2$ ) for each experimental condition.

\section{Results}

Specificity of the oliginucleotide primers. The possibility of amplifying specific $\beta$-AR genes was first investigated on genomic DNA. As shown in Fig. 1, amplification of $0.1 \mu \mathrm{g}$ of DNA with the $\beta_{2}$ primers gave a single band of the expected size ( $343 \mathrm{bp}$ ). Under our conditions, a DNA fragment was detected by ethidium-bromide staining when amplification was performed from as low as $0.1 \mathrm{ng}$ ( $\sim 30$ targets) of genomic DNA (data not shown). Fig. 1 also shows that a set of restriction enzymes chosen from the published sequence $(18,19)$ always gave bands of the expected size. This restriction profile definitively identifies the amplification product as a $\beta_{2}$ fragment. The same kind of experiment also validated the primers designed for $\beta_{1}$ amplification (data not shown).

Detection of $\beta_{1}$ and $\beta_{2}$-AR mRNAs in isolated thick ascending limbs by RT-PCR. The following experiments were performed to assess $\beta$-AR mRNA expression in the CTAL and MTAL (Fig. 2). In all cases, single bands of the expected size $\left(\beta_{1}, 376 \mathrm{bp} ; \beta_{2}, 343 \mathrm{bp}\right)$ were obtained. In both the CTAL and MTAL, amplification with the $\beta_{2}$ primers gave very faint bands (Fig. 2). With the $\beta_{1}$ primers, the band intensities were definitely higher. The $\beta_{1}$ signal obtained from the CTAL RNA sample appears more intense than the one obtained with the MTAL RNAs. The amplification was fully RNA dependent, as shown by the uniformly negative results obtained without reverse transcriptase on the same RNA samples.

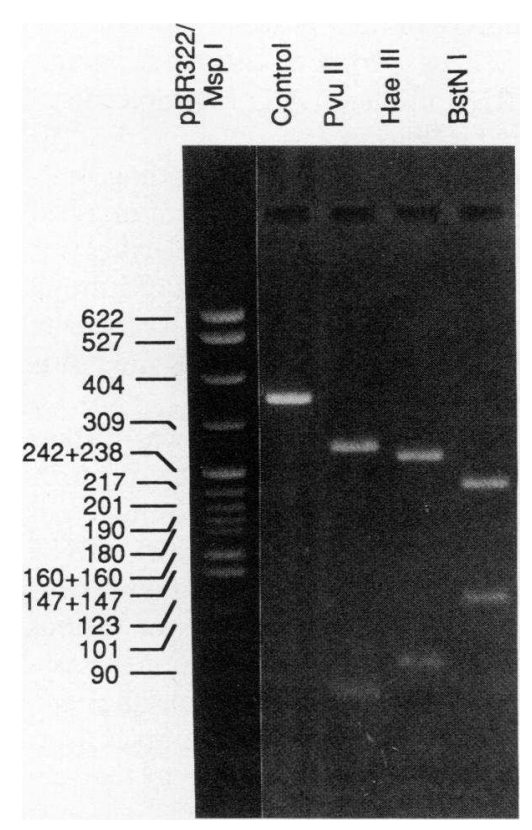

Figure 1. Amplification of rat genomic DNA with specific $\beta_{2}$ primers. Amplification was performed from $0.1 \mu \mathrm{g}$ of rat genomic DNA using 35 PCR cycles. DNA was then extracted with phenol-chloroformisoanyl alcohol, precipitated with ethanol, and left uncut (Control) or digested with the indicated enzyme. The fragments were fractionated on a 3\% agarose gel and stained with ethidium bromide. The expected band sizes were (bp): control, 343; PvulI, 265 +78 ; HaelII, 247 + 96; BstnI, $220+123$. The left lane shows the molecular weight marker ( $1 \mu \mathrm{g}$ of pBR322 digested with MspI).

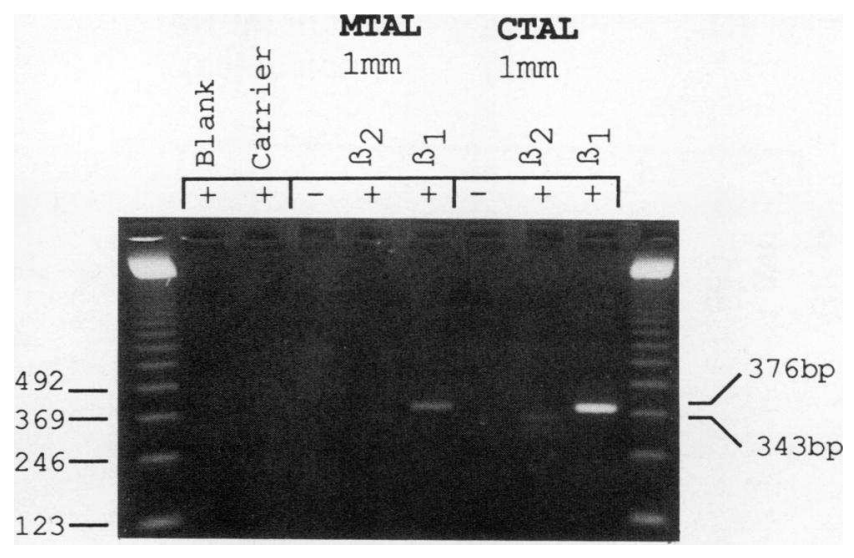

Figure 2. Detection of $\beta_{1}$ - and $\beta_{2}$-AR mRNAs in isolated thick ascending limbs by RT-PCR. RNAs were extracted from pools of microdissected CTAL or MTAL segments (total length, $15 \mathrm{~mm}$ ). Aliquots corresponding to RNAs originating from $1 \mathrm{~mm}$ of tubule were submitted to RT-PCR ( 35 PCR cycles). $20 \mu$ l of the RT-PCR reaction were loaded on a $2 \%$ agarose gel and the DNA fragments were stained with ethidium bromide. The assay was carried out in the absence ( - ) or presence $(+)$ of reverse transcriptase. Blank, reaction performed without RNA; Carrier, reaction performed on a sample treated similarly to the tubular segments and containing $10 \mu \mathrm{g}$ of yeast RNA but no isolated tubules. These reactions were carried out with the $\beta_{2}$ primers and were also negative when using the $\beta_{1}$ primers. Left and right lanes shows the molecular weight marker (123-bp DNA ladder; Bethesda Research Laboratories).

Attempts to quantify even roughly the absolute mRNA levels in this experiment were impeded by the lack of external or internal standards in the RT-PCR assay and the low sensitivity of ethidium-bromide staining. This detection method requires a high number of PCR cycles to generate detectable amounts of DNA molecules. Under these conditions, however, exponential accumulation is not maintained throughout the PCR reaction, resulting in a lack of proportionality between the amount of RNA in the sample and the DNA product (23). To overcome these limitations, a quantitative assay was set up. To reduce the number of cycles and lower the detection threshold of the method, a radiolabeled deoxynucleotide was included in the assay.

Quantitative analysis of $\beta_{1}$ and $\beta_{2}-A R m R N A$. The requirements for a quantitative RT-PCR assay, especially the number of molecules to be introduced for a given number of cycles, were first studied by amplifying separately wild-type and mutant mRNAs. Fig. 3 illustrates such an experiment. As expected, single bands of identical sizes were obtained from CTAL and mutant RNAs. More importantly, Fig. 3 shows that, under our conditions, the amount of DNA molecules formed clearly increased with the number of $\beta_{1}$-AR mRNA molecules introduced in the assay. Scanning analysis of the autoradiograms revealed a linear increase of up to 2,500 starting molecules. Between 2,500 and 12,500 the output signal increased by a factor of 4.3 , suggesting that linearity was not fully maintained. In a similar experiment performed using 12,500 mutant RNA molecules as starting material, we calculated from the radioactivity incorporated that the end product concentration was $0.5 \times 10^{-8} \mathrm{M}$. On the basis of the observation that the concentration of Taq polymerase in the assay becomes limiting when DNA concentration reaches $10^{-8} \mathrm{M}$ 


\section{RT * CTAL Mutant mRNA \\ (mm) (molecules)

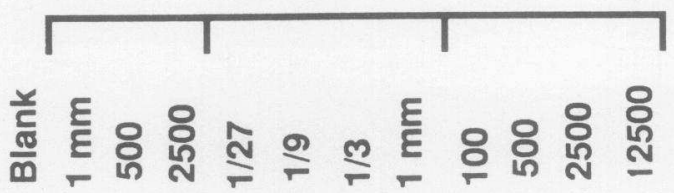

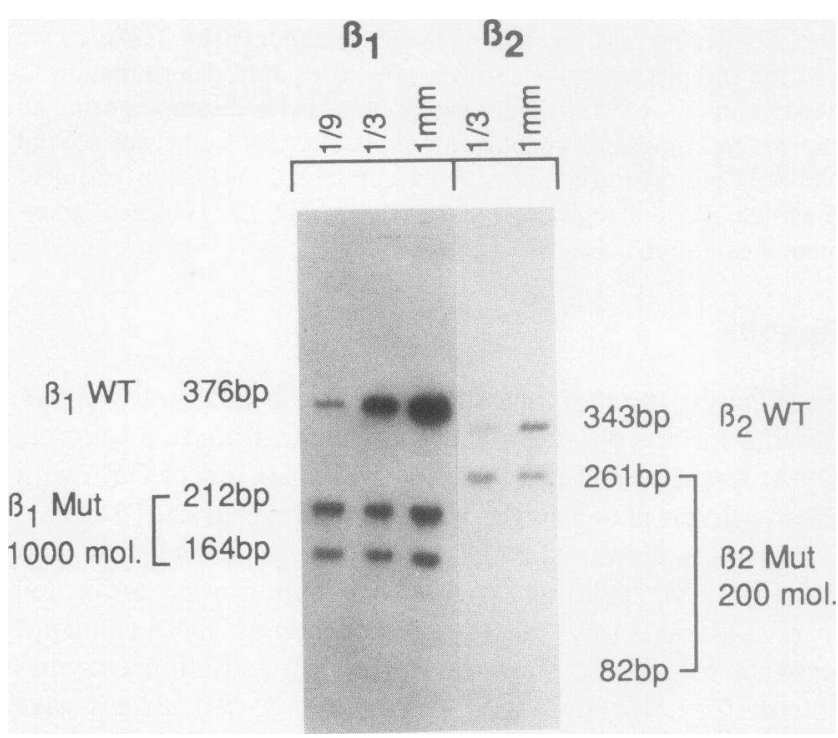

Figure 4. Quantitative analysis of $\beta_{1}$ - and $\beta_{2}$-AR mRNAs in the CTAL: coamplification of wild-type and mutant RNAs. CTAL samples and mutated $\beta$-AR RNAs were amplified simultaneously using variable amounts of CTAL RNAs and constant amounts $\left(\beta_{1}, 1,000\right.$ molecules; $\beta_{2}, 200$ molecules) of the internal standard. The DNA fragments formed from wild-type and mutant RNAs were discriminated by digestion with Xhol. Wild-type DNA fragments $(b p): \beta_{1}$, $376 ; \beta_{2}, 343$. Mutant DNA fragments $(b p): \beta_{1}, 212+164 ; \beta_{2}, 262$ +81 . These fragments were fractionated on a $3 \%$ agarose slab gel and detected by autoradiography.

cules $/ \mathrm{mm}$. This is consistent with reports indicating a lower stimulation of adenylyl cyclase by isoproterenol in the MTAL than in the CTAL $(2,6)$ (In both the mouse and rat kidney, isoproterenol-sensitive adenylyl cyclase was first reported to be present in CTAL but not in MTAL [6]. More recently, it was demonstrated that adenylyl cyclase is activated by isoproterenol in both segments in the mouse [2]. In preliminary studies we compared isoproterenol-dependent cAMP accumulation in the rat MTAL and CTAL. We found a small but significant increase of cAMP accumulation in the MTAL $[\sim 30 \%$ of that observed in the CTAL].). This experiment also confirms the very low level of $\beta_{2}$-AR mRNA in the CTAL ( 137 molecules/ $\mathrm{mm}$ for the sample analyzed in Fig. 5).

$\beta_{1}$ - and $\beta_{2}$-AR mRNA levels in the thick ascending limb were measured in several experiments, which are summarized in Table II. In the CTAL, the number of mRNA molecules was always markedly higher for $\beta_{1}$ - than for $\beta_{2}$-AR, demonstrating the preponderance of the $\beta_{1}$-AR mRNA. In the MTAL, despite the low number of observations, it is clear that $\beta_{1}$-AR mRNA is also predominant.

The accuracy of the previous determinations was further tested by adding known amounts of mutant $\beta_{1}$ mRNA during the extraction procedure. This approach should eliminate potential losses as contributing to underestimation of the mRNA content of biological samples. Fig. 6 gives results of an experiment in which RNAs were isolated from CTALs of various length (range $0.4-2.15 \mathrm{~mm}$ ). A significant correlation was observed between the number of $\beta_{1}$-AR mRNA molecules and the tubular length. $\beta_{1}$-AR mRNA levels in these samples averaged 2,500 molecules per $\mathrm{mm}$, a value very close to that ob- 


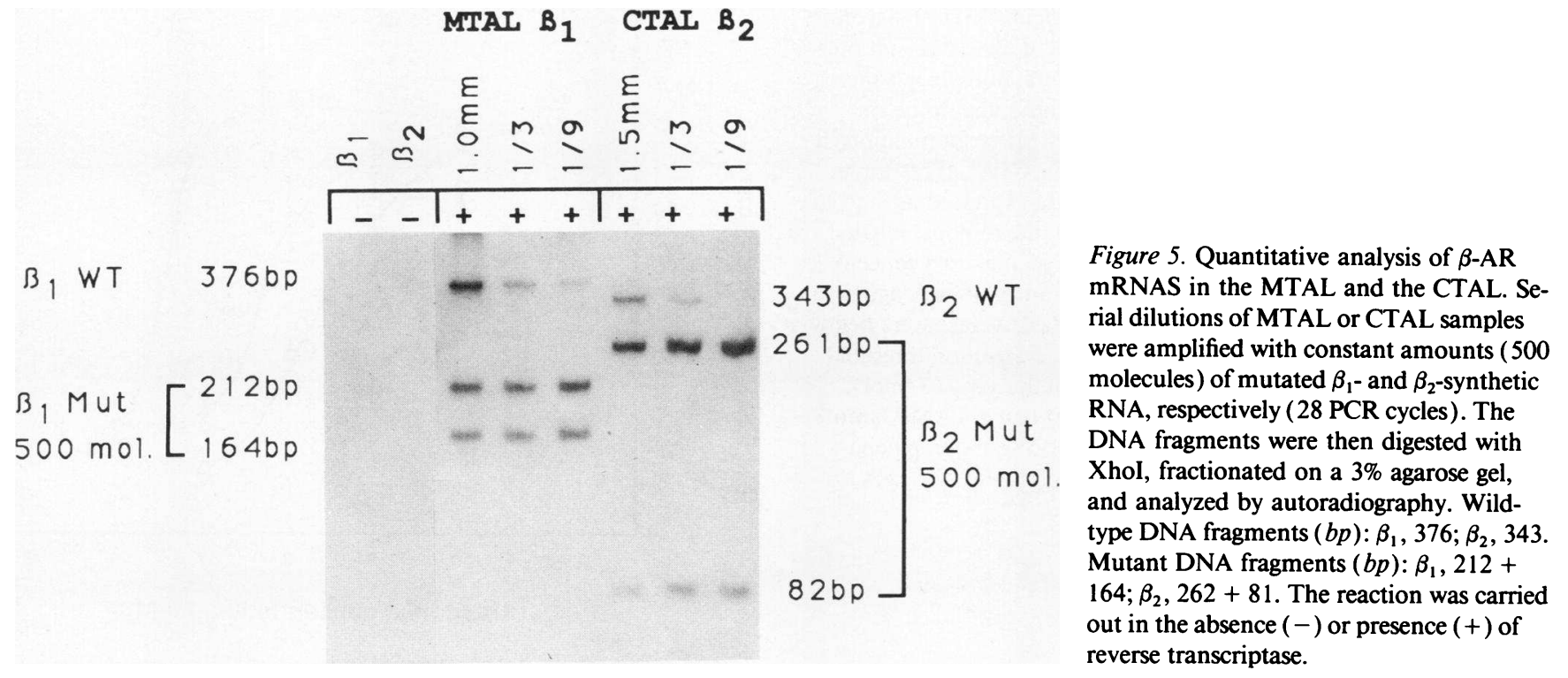

tained when the internal standard was added only for the RTPCR reaction step. This experiment demonstrates that our microprocedure of extraction allows complete RNA recovery.

Pharmacological properties of $\beta$-ARs in the CTAL. The markedly different levels of $\beta_{1}$ - and $\beta_{2}$-AR mRNAs in the CTAL prompted us to study its functional consequences on agonist-induced cAMP accumulation. As shown in Fig. 7, the rank order of potency for stimulating cAMP accumulation was isoproterenol $>$ norepinephrine $>$ epinephrine, a profile entirely typical of a $\beta_{1}$-AR $(8,17)$. Moreover, the $\beta_{1}$ antagonist CGP 20712A was 15 times more potent than the $\beta_{2}$ antagonist ICI 118551 in inhibiting isoproterenol-induced cAMP accumulation (Fig. 8). CGP 12177A, a nonselective $\beta$-AR antago-

Table II. $\beta_{I^{-}}$and $\beta_{2}$-AR $M R N A$ Levels in the CTAL and MTAL

\begin{tabular}{|c|c|c|c|c|}
\hline \multirow[b]{3}{*}{ Experiment } & \multicolumn{4}{|c|}{ mRNA content } \\
\hline & \multicolumn{2}{|c|}{ CTAL } & \multicolumn{2}{|c|}{ MTAL } \\
\hline & $\beta_{1}$ & $\beta_{2}$ & $\beta_{1}$ & $\beta_{2}$ \\
\hline & \multicolumn{4}{|c|}{ molecules $/ \mathrm{mm}$} \\
\hline 1 & 3,078 & 244 & 529 & 117 \\
\hline 2 & 5,453 & 138 & - & - \\
\hline 3 & 2,392 & 90 & - & - \\
\hline 4 & 3,385 & 185 & - & - \\
\hline 5 & 1,895 & 137 & - & - \\
\hline 6 & - & - & 565 & 119 \\
\hline Mean & 3,241 & $159^{*}$ & 547 & 118 \\
\hline SEM & 611 & 26 & & \\
\hline
\end{tabular}

RNAs extracted from isolated CTALs or MTALs were analyzed by quantitative RT-PCR, as described in Figs. 4 and 5. The same RNA preparation was always tested for both $\beta_{1}$ and $\beta_{2}$ mRNA levels. * Significant difference between the number of $\beta_{1}$ and $\beta_{2}$ mRNA molecules in the CTAL $(P<0.01$, paired t test). nist (10), inhibited isoproterenol action with a $K_{\mathrm{i}}$ even lower than that of CGP 20712A (Fig. 8). This is in agreement with the different affinities of CGP 12177A and CGP 20712A for $\beta_{1}$-AR (24). On the other hand, CGP 12177A has partial agonistic properties on $\beta_{3}$-AR $(11,24)$. Nevertheless, as shown on Fig. 8, it completely abolished isoproterenol-dependent cAMP accumulation and, when tested alone, did not measurably increase cAMP formation (data not shown). These data indicate that $\beta_{3}$-AR should not contribute significantly to cAMP synthesis in this nephron segment, and consequently, that $\beta_{1}$-AR is the predominant receptor subtype responsible for adenylyl cyclase activation.

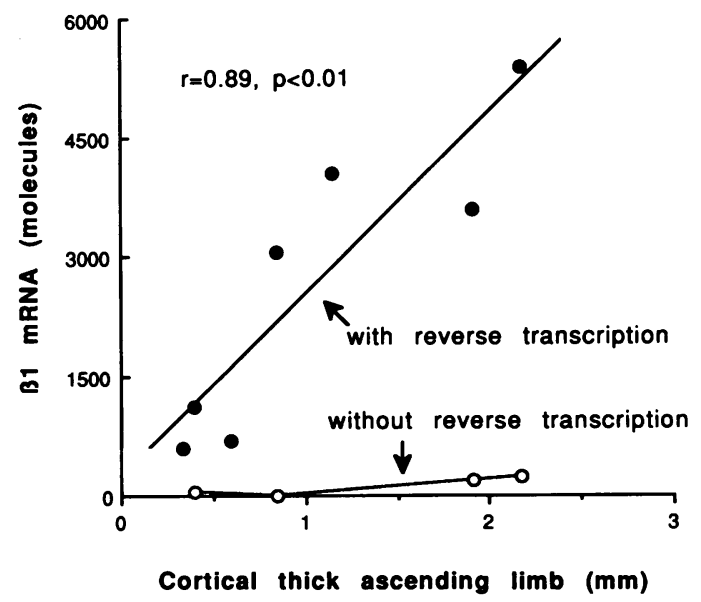

Figure 6. Correlation between the amount of $\beta_{1}$-AR mRNAs and the tubular length. RNAs were extracted from microdissected CTALs (0.4-2.15 mm). Known amounts of mutated $\beta_{1}$ RNAs were added just before extraction. RT-PCR ( 28 PCR cycles) was then performed as described in Fig. 4 except that the mutated $\beta_{1}$ RNA was not further added to the reaction. Some samples were halved to perform the assay in the presence or absence of RT enzyme, as indicated. Linear regression equation: $y=2,257 x+267$. 


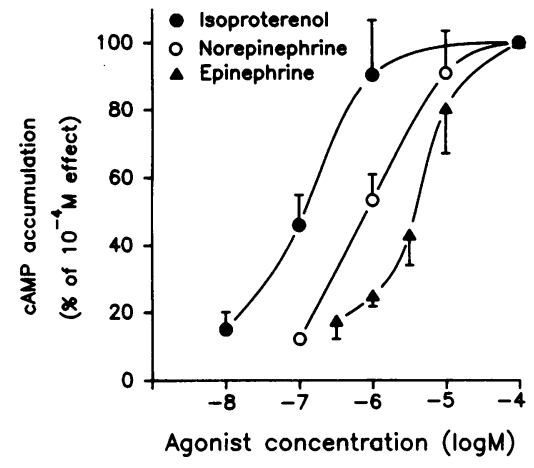

Figure 7. Dose-dependent effects of isoproterenol, norepinephrine, and epinephrine on cAMP accumulation in the CTAL. The results are expressed as percent of the response elicited by a maximal concentration of each agonist. Basal values were below the detection threshold of the assay ( $3 \mathrm{fmol})$. Maximal cAMP ( $\mathrm{fmol} /$ $\mathrm{mm} \cdot 4 \mathrm{~min}$ ) accumulations were isoproterenol, $58 \pm 8$; norepinephrine, $53 \pm 12$; epinephrine, $58 \pm 15$ ( $n=3-5$ experiments for each agonist).

\section{Discussion}

This study demonstrates the differential expression of $\beta_{1}$ and $\beta_{2}$-AR mRNA in the thick ascending limb of Henle's loop. The high levels of $\beta_{1}$-AR mRNAS were associated with a profile of agonist-induced cAMP accumulation typical of $\beta_{1}$-ARs. These data were obtained using a method that allows absolute mRNA quantitation through a RT-PCR assay that is sensitive enough to detect 100 target copies. The method can be applied to measure mRNAs obtained from as few as 30 cells.

Several methods using RT-PCR have already been proposed for relative or absolute quantitation of RNAs. Relative quantitation has been used to detect aldose reductase, $\mathrm{Na} / \mathrm{H}$ antiporter, and ANF receptor mRNAs in single nephron segments (25-27). This method, although useful to roughly evaluate gene expression, is limited in its applications. Robinson and Simon (28) attempted to quantitate mRNA levels using an external standard. In this case, known amounts of synthetic RNAs and experimental samples were amplified in separate RT-PCR reactions. However, this method does not correct the yield of product for reaction-to-reaction variation and its application for accurate quantitation is uncertain (29). This problem is circumvented and reliability is greatly improved through coamplification with a single pair of primers of the natural mRNA target and of a synthetic RNA, used as an internal standard. The internal standard is either of different size than the wild-type species $(29,30)$ or only differs by a single base substitution to introduce a new restriction site in the cDNA $(15,29)$. In each case, the products obtained from synthetic and wild-type RNAs can be separated by gel electrophoresis.

Our method is close to the one described by Becker-André and Hahlbrock (15), i.e., the PCR-aided transcript titration assay (PATTY) method, with notable modifications that make it easier. Our assay is performed in the presence of one labeled deoxynucleotide. This allows direct detection of the product by autoradiography without additional steps for transfer and hybridization. The amounts of natural and synthetic RNAs introduced in the assay are 1,000-fold lower than in other methods $(15,29)$ to ensure an exponential accumulation all along the PCR reaction. If such was not the case, the DNA strands not used as templates could partly reassociate and form heterodimeric DNA species resistant to Xhol digestion.

To demonstrate the absence of heteroduplex molecules in

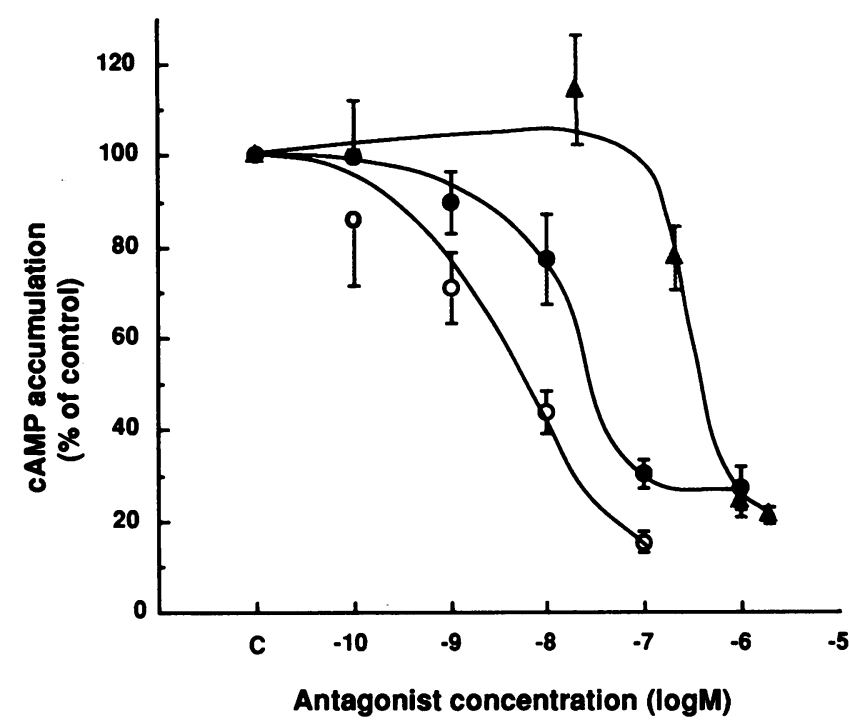

Figure 8. Inhibition of isoproterenol-induced cAMP accumulation by nonselective (CGP 12177A), $\beta_{1}$-(CGP 20712A), and $\beta_{2^{-}}$(ICI 118551 ) adrenergic antagonists. Each point is the mean value of 7 to 17 replicate samples obtained from two experiments. The results are expressed as percent of the effect of isoproterenol $(0.2 \mu \mathrm{M})-$ induced cAMP accumulation, which averaged $28 \pm 3 \mathrm{fmol} / \mathrm{mm} \cdot 4 \mathrm{~min}(n=6$ experiments). cAMP accumulation in the presence of $10^{-7}-10^{-4} \mathrm{M}$ concentrations of CGP 12177A was below the detection threshold of the assay $(<3 \mathrm{fmol} / \mathrm{mm})$, indicating complete inhibition. 0 , CGP 12177A; •, CGP 20712A; ^, ICI 118551.

our assay, the CTAL samples amplified with the $\beta_{1}$ primers and described in Table II (line 1 ) were 10 or 100 times diluted, fully denaturated, and submitted to an additional PCR cycle with fresh enzyme before Xhol digestion and electrophoresis (15). The ratio of the wild-type and mutant DNA molecules was unaltered. Consequently, the calculated mRNA level was unchanged, being $3,078,3,133$, and 2,703 for native, 10 times, and 100 times diluted samples, respectively. Therefore, our experimental conditions rule out the presence of heterodimeric molecules. With the advantage of labeling the product, it was possible to quantitate 100 molecules after only 28 PCR cycles.

Physiological significance of the differential expression of $\beta_{1}$ and $\beta_{2}-A R m R N A S$. $\beta_{1}$-AR mRNA levels in the CTAL averaged 3,000 molecules $/ \mathrm{mm}$. Considering that the number of cells approximates $300 / \mathrm{mm}$ in this nephron segment (30a), then the amount of $\beta_{1}$-AR mRNA is of about 10 copies/cells. Conversely, the $\beta_{2}$-AR mRNA level should be $<1$ copy/cell. This very faint level may correspond to background expression of the $\beta_{2}$-AR gene. The predominance of $\beta_{1}$-AR mRNA is in close agreement with the typical $\beta_{1}$-AR sensitivity of the CTAL and demonstrates coordinated differences of $\beta$-AR subtypes at the protein and mRNA levels. The contribution of a third or "atypical" $\beta$-AR to catecholamine action in the CTAL is unlikely since CGP $12177 \mathrm{~A}$, which elicits $30-40 \%$ of the effect of isoproterenol in cells bearing $\beta_{3}$-ARs (24), was unable to stimulate cAMP accumulation and completely inhibited isoproterenol action. In addition, when RT-PCR was performed using $\beta_{3}$-AR selective primers, no detectable product (assessed by ethidium-bromide staining) was obtained from the CTAL whereas, as expected $(11,13), \beta_{3}$-AR transcripts were evi- 
denced in the brown adipose tissue (unpublished observations from our laboratory). All these data, therefore, reveal a molecular basis for the predominant expression of the $\beta_{1}$-AR in the CTAL and are consistent with previous autoradiographic studies showing that $\beta$-adrenoceptors of the thick ascending limb are almost exclusively of the $\beta_{1}$ subtype (31-33).

Norepinephrine, the neurotransmitter of sympathetic nerves, is the preferential ligand of $\beta_{1}$-ARs. Consequently, the thick ascending limb should be more sensitive to variations of the local concentrations of norepinephrine than to circulating epinephrine. The thick ascending limb has monoaminergic innervation (34), and low frequency renal nerve stimulation has been shown to increase $\mathrm{Na}$ and $\mathrm{Cl}$ reabsorption in the loop of Henle (35). We therefore suggest that norepinephrine, through $\beta_{1}$-ARs, is responsible for many of the physiological effects assigned to $\beta$-agonists in this nephron segment, including the stimulation of $\mathrm{NaCl}, \mathrm{Ca}$ and $\mathrm{Mg}$ reabsorption (2).

The lack of significant expression of the $\beta_{2}$-AR gene in the CTAL indicates that this nephron segment will be a useful model to study the regulation of the $\beta_{1}-\mathrm{AR}$ and to assess the factors contributing to the emergence of $\beta_{2}$-AR. Recently, a human neurotumoral cell line that expresses $\beta_{1}$ - but not $\beta_{2}$ ARs has been used to study the mechanism of $\beta_{1}$-AR desensitization (36). The cAMP-dependent protein kinase A, but not the $\beta$-adrenergic receptor kinase, was responsible for desensitization of the human $\beta_{1}$-AR to isoproterenol. The mechanisms of desensitization of the rat and human $\beta_{1}$-AR may nevertheless be different since the rat $\beta_{1}$-AR has more potential phosphorylation sites for $\beta$-adrenergic receptor kinase $(8,17)$. Desensitization to isoproterenol has also been reported in the CTAL (21), and investigating the kinase(s) involved in this process is an attractive area for future studies. Furthermore, our RT-PCR assay will make possible to study the regulatory mechanisms of the $\beta_{1}$-AR at the mRNA level. Regulation of the $\beta_{2}$-AR has been shown to involve alterations of both the receptor protein and its mRNA $(37,38)$. However, nothing is known on the possible effects of adrenergic agents on the steady state level of $\beta_{1}$-AR mRNA.

In conclusion, this study demonstrates the possibility of measuring minute amounts of $\beta_{1}$ and $\beta_{2}$-AR mRNAs by RTPCR. This assay is sensitive enough to detect mRNA in 30 cells and will be useful to characterize $\beta$-AR subtypes and establish their regulation. In the thick ascending limb, $\beta_{1}$-AR mRNA levels were 20 -fold higher than those of $\beta_{2}$-AR. The corresponding adrenergic sensitivity supports the notion that norepinephrine, rather than epinephrine, is responsible for the stimulation of ion transport in this portion of the nephron.

\section{Acknowledgments}

We thank Drs. P. Pradeddes and J. Grassi for their help in measuring cyclic AMP. The technical assistance of C. Doira was greatly appreciated.

\section{References}

1. Iino, Y., J. L. Troy, and B. M. Brenner. 1981. Effect of catecholamines on electrolyte transport in cortical collecting tubule. J. Membr. Biol. 61:67-73.

2. Bailly C., M. Imbert-Teboul, N. Roinel, and C. Amiel. 1990. Isoproterenol increases $\mathrm{Ca}, \mathrm{Mg}$ and $\mathrm{NaCl}$ reabsorption in mouse thick ascending limb. Am.J. Physiol. 258(Renal Fluid Electrolyte Physiol. 27):F1224-F1231.
3. De Fronzo, R. A., B. Stanton, G. Klein-Robbenhaar, and G. Giebisch. 1983. Inhibitory effect of epinephrine on renal potassium secretion: a micropuncture study. Am. J. Physiol. 245(Renal Fluid Electrolyte Physiol. 14):F303-F311.

4. Kimmel P. L., and S. Goldfark. 1984. Effects of isoproterenol on potassium secretion by the cortical collecting tubule. Am. J. Physiol. 246(Renal Fluid Electrolyte Physiol. 15):F804-F810.

5. Schuster, V. L. 1985. Cyclic adenosine monophosphate-stimulated bicarbonate secretion in rabbit cortical collecting tubules. 1985. J. Clin. Invest. 75:2056-2064.

6. Morel F., M. Imbert-Teboul, and D. Chabardès. 1981. Distribution of hormone-dependent adenylate-cyclase in the nephron and its physiological significance. Annu. Rev. Physiol. 43:569-581.

7. Rouffignac C. de, A. Di Stefano, M. Wittner, N. Roinel, and J. M. Elalouf. 1991. Consequences of differential effects of ADH and other peptide hormones on thick ascending limb of mammalian kidney. Am. J. Physiol. 260(Regulatory Integrative Comp. Physiol. 29):R1023-R1035.

8. Frielle, T., S. Collins, K. W. Daniel, M. G. Caron, R. J. Lef kowitz, and B. K. Kobilka. 1987. Cloning of the cDNA for the human $\beta_{1}$-adrenergic receptor. Proc. Natl. Acad. Sci. USA. 84:7920-7924.

9. Dixon, R. A. F., B. K. Kobilka, D. J. Strader, J. L. Benovic, H. G. Dohlman, T. Frielle, M. A. Bolanowski, C. D. Bennet, E. Rands, R. E. Diehl, et al. 1986. Cloning of the gene and cDNA for mammalian $\beta$-adrenergic receptor and homology with rhodopsin. Nature (Lond.). 321:75-79.

10. Emorine, L. J., S. Marullo, M.-M. Briend-Sutren, G. Patey, K. Tate, C. Delavier-Klutchko, and A. D. Strosberg. 1989. Molecular characterization of the human $\beta_{3}$-adrenergic receptor. Science (Wash. DC). 245:1118-1121.

11. Nahmias, C., N. Blin, J. M. Elalouf, M. G. Mattei, A. D. Strosberg, and L. J. Emorine. 1991. Molecular characterization of the mouse $\beta_{3}$-adrenergic receptor: relationship with the atypical receptor of adipocytes. EMBO (Eur. Mol. Biol. Organ.) J. 10:3721-3727.

12. Fève, B., L. J. Emorine, M.-M. Briend-Sutren, F. Lasnier, A. D. Strosberg, and J. Pairault. 1990. Differential regulation of $\beta_{1}$ and $\beta_{2}$-adrenergic receptor protein and mRNA levels by glucocorticoids during 3T3-F442A adipose differentiation. J. Biol. Chem. 265:16343-16349.

13. Muzzin, P., J. P. Revelli, F. Kuhne, J. D. Gocayne, W. R. McCombie, J. C. Venter, J. P. Giacobino, and C. M. Fraser. 1991. An adipose tissue-specific $\beta$-adrenergic receptor. Molecular cloning and down-regulation in obesity. J. Biol. Chem. 266:24053-24058.

14. Rappolee, D. A., A. Wang, D. Mark, and Z. Werb. 1989. Novel method for studying mRNA phenotypes in single or small number of cells. J. Cell. Biochem. 39:1-11.

15. Becker-André, M., and K. Hahlbrock. 1989. Absolute mRNA quantification using the polymerase chain reaction (PCR). A novel approach by a PCR aided transcript titration assay (PATTY). Nucleic Acids Res. 22:9437-9446.

16. Ausubel, F. M., R. Brent, R. E. Kingston, D. D. Moore, J. G. Seidman, J. A. Smith, and K. Struhl, editors. 1991. Current Protocols in Molecular Biology. Greene Publishing Associates and Wiley-Interscience, New York.

17. Machida, C. A., J. R. Bunzow, R. P. Searles, H. Van Tol, B. Tester, K. A. Neve, P. Teal, V. Nipper, and O. Civelli. 1990. Molecular cloning and expression of the rat $\beta_{1}$-adrenergic receptor gene. J. Biol. Chem. 265:12960-12965.

18. Gocayne, J., D. A. Robinson, M. G. Fitzgerald, F. Z. Chung, A. R. Kerlavage, K. A. Lentes, J. Lain, C. D. Wang, C. M. Fraser, and J. C. Venter. 1987. Primary structure of rat cardiac $\beta$-adrenergic and muscarinic cholinergic receptors obtained by automated DNA sequence analysis: further evidence for a multigene family. Proc. Natl. Acad. Sci. USA. 84:8296-8300.

19. Buckland, P. R., R. M. Hill, S. T. Tidmarsh, and P. M. McGuffin. 1990. Primary structure of the rat $\beta_{2}$-adrenergic receptor gene. Nucleic Acids Res. 18:682.

20. Kunkel, T. A., J. D. Roberts, and R. A. Zakour. 1987. Rapid and efficient site-specific mutagenesis without phenotypic selection. Methods Enzymol. 154:367-382.

21. Dublineau I., P. Pradelles, C. de Rouffignac, and J. M. Elalouf. 1992. Differential short-term desensitization to vasopressin, isoproterenol, glucagon, parathyroid hormone and calcitonin in the thick ascending limb of rat kidney. Pfluegers Arch. Eur. J. Physiol. 420:16-22.

22. Chomczynski P., and N. Sacchi. 1987. Single step method of RNA isolation by acid guanidinium thiocyanate-phenol-chloroform extraction. Anal. Biochem. 162:156-159.

23. Bloch, W. 1991. A biochemical perspective of the polymerase chain reaction. Biochemistry. 30:2735-2747.

24. Feve, B., L. J. Emorine, F. Lasnier, N. Blin, B. Baude, C. Nahmias, A. D. Strosberg, and J. Pairault. 1991. Atypical $\beta$-adrenergic receptor in 373-F442A adipocytes. Pharmacological and molecular relationship with the human $\beta_{3}$ adrenergic receptor. J. Biol. Chem. 266:20329-20336.

25. Moriyama, T., H. R. Murphy, B. M. Martin, and A. Garcia-Perez. 1990. Detection of specific mRNAs in single nephron segments by use of the polymerase chain reaction. Am. J. Physiol. 258(Renal Fluid Electrolyte Physiol. 27):F1470-F1474. 
26. Krapf, R., and M. Solioz. 1991. Na/H antiporter mRNA expression in single nephron segments of rat kidney cortex. J. Clin. Invest. 88:783-788.

27. Terada, Y., T. Moriyama, B. M. Martin, M. A. Knepper, and A. GarciaPerez. 1991. RT-PCR microlocalization of mRNA for guanylyl cyclase-coupled ANF receptor in rat kidney. Am. J. Physiol. 261 (Renal Fluid Electrolyte Physiol. 30):F1080-F1087

28. Robinson, M. O., and M. I. Simon. 1991. Determining transcript number using the polymerase chain reaction: Pgk-2, mP2, and PGK-2 transgene mRNA levels during spermatogenesis. Nucleic Acids Res. 19:1557-1562.

29. Gilliland, G., S. Perrin, K. Blanchard, and H. F. Bunn. 1990. Analysis of cytokine mRNA and DNA: detection and quantitation by competitive polymerase chain reaction. Proc. Natl. Acad. Sci. USA. 87:2725-2729.

30. Wang, A. M., M. V. Doyle, and D. F. Mark. 1989. Quantitation of mRNA by the polymerase chain reaction. Proc. Natl. Acad. Sci. USA. 86:9717-9721.

30a.Vandewalle, A. 1986. Heterogeneity of uridine incorporation along the rabbit nephron. II. Effect of DOCA. Am. J. Physiol. 246(Renal Fluid Electrolyte Physiol. 15):F427-F436.

31. Münzel, P. A., D. P. Healy, and P. A. Insel. 1984. Autoradiographic localization of $\beta$-adrenergic receptors in rat kidney slices using [ ${ }^{125}$ I] iodocyanopindolol. Am. J. Physiol. 246(Renal Fluid Electrolyte Physiol. 15):F240-F245.
32. Summers, R. J., J. A. Stephenson, and M. J. Kuhar. 1985. Localization of Beta adrenoceptor subtypes in rat kidney by light microscopic autoradiography. J. Pharmacol. Exp. Ther. 232:561-569.

33. Engel, G., R. Maurer, K. Perrot, and B. P. Richardson. 1985. $\beta$-Adrenoceptor subtypes in sections of rat and guinea-pig kidney. Naunyn-Schmiedeberg's Arch. Pharmacol. 328:354-357.

34. Barajas, L., and K. Powers. 1988. Innervation of the thick ascending limb of Henle. Am. J. Physiol. 255(Renal Fluid Electrolyte Physiol. 24):F343-F348.

35. Dibona, G. F., and L. L. Sawin. 1982. Effect of renal nerve stimulation on $\mathrm{NaCl}$ and $\mathrm{H}_{2} \mathrm{O}$ transport in Henle's loop of the rat. Am. J. Physiol. 243(Renal Fluid Electrolyte Physiol. 12):F576-F580.

36. Zhou, X. H., and P. H. Fishman. 1991. Desensitization of the human $\beta_{1}$-adrenergic receptor. Involvement of the cyclic AMP-dependent but not a receptor-specific protein kinase. J. Biol. Chem. 266:7462-7468.

37. Hadcock, J. R., and C. R. Malbon. 1988. Down-regulation of $\beta$-adrenergic receptors: agonist-induced reduction in receptor mRNA levels. Proc. Natl. Acad. Sci. USA. 85:5021-5025.

38. Collins, S., M. Bouvier, M. A. Bolanowski, M. G. Caron, and R. J. Lef kowitz. 1989. cAMP stimulates transcription of the $\beta_{2}$-adrenergic receptor gene in response to short-term agonist exposure. Proc. Natl. Acad. Sci. USA. 86:48534857. 